\title{
Food allergy: is desensitization an effective treatment strategy in patients with peanut allergy?
}

\section{Alergia alimentar: é a dessensibilização uma estratégia de tratamento efetiva em pacientes com alergia ao amendoim?}

\author{
André Leonardo Nogueira Farias ${ }^{1}$. Humberto Farias Castelo Branco Junior ${ }^{2}$. Halisson Caio Freitas Castelo \\ Branco $^{3}$. \\ 1 Universidade de Liverpool (UoL), Liverpool, Reino Unido, Universidade Federal do Ceará, Fortaleza, Ceará, Brasil. 2 Centro \\ Universitário Christus (Unichristus), Fortaleza, Ceará, Brasil. 3 Universidade de Fortaleza (Unifor), Fortaleza, Ceará, Brasil.
}

\begin{abstract}
Background: Adverse reactions to foods are divided in two main groups: food intolerance (non-immune process) and food allergies (immune-mediated process). The food allergy (FA) is a common and on rise condition in population. Although there is possibility of preventive or symptomatic relief through use of antihistamines and corticosteroids, it lacks full cure. Heretofore, it was believed that the only really effective treatment against this condition would be complete allergen restriction. Aim: To review the immune mechanisms related with food allergy and propose a new therapeutic technic called desensitization. Methods: Non-systematic review. Findings: FA is more common in children and in patients with other allergic conditions. Allergies related to peanut/milk/ egg/fish/crustacean shellfish are more common and permanent. FA is a complex and multifactorial process, which mixes genetic and environmental factors. Conclusion: Food allergy is a health problem worldwide. Scientists still need a better understand of the immune mechanisms involved in the food allergy pathogenesis \& in the human susceptibility to allergens. Therefore, scientists will need to improve definitive therapeutic modalities to avoid dramatic outcomes.
\end{abstract}

Keywords: Immune system diseases. Anaphylaxis. Food hypersensitivity. Peanut hypersensitivity.

\section{RESUMO}

Introdução: as reações adversas aos alimentos são divididas em dois grupos principais: intolerância alimentar (processo não imune) e alergias alimentares (processo imunomediado). A alergia alimentar é uma condição comum e crescente na população. Embora exista uma possibilidade de alívio preventivo ou sintomático através do uso de anti-histamínicos e corticosteróides, não possui cura completa. Até agora, acreditava-se que o único tratamento realmente eficaz contra esta condição seria uma restrição completa dos alérgenos. Objetivo: Revisar os mecanismos imunológicos relacionados com a alergia alimentar e propor uma nova técnica terapêutica chamada desensibilização. Métodos: revisão não sistemática. Resultados: Patologia mais comum em crianças e em pacientes com outras condições alérgicas. As alergias relacionadas ao amendoim/leite/ovo/peixe/crustáceos são mais comuns e permanentes. A alergia alimentar é um processo complexo e multifatorial, que mistura fatores genéticos e ambientais. Conclusão: A alergia alimentar é um problema de saúde em todo o mundo. Os cientistas ainda precisam de uma melhor compreensão dos mecanismos imunológicos envolvidos na patogênese da alergia alimentar e na susceptibilidade humana aos alérgenos. Portanto, os cientistas precisarão melhorar as modalidades terapêuticas definitivas para evitar desfechos dramáticos.

Palavras-chave: Doenças imunológicas. Anafilaxia. Alergia a alimentos. Hipersensibilidade a amendoim.

Corresponding author: André Leonardo Nogueira Farias, Departamento de Patologia e Medicina Legal, Faculdade de Medicina, Universidade Federal do Ceará, Rua Monsenhor Furtado, Rodolfo Teófilo, Fortaleza, Ceará. CEP: 60441-750. Phone: +55 85 3366-8864. E-mail: andrefarias382@gmail.com Conflict of interests: The authors have no conflicts of interest to declare.

Received: 29 Sep 2017; Revised: 18 May 2018; Accepted: 27 May 2018. 


\section{INTRODUCTION}

\section{Definition of food allergy}

Adverse reactions to foods are represented for any abnormal reaction to food intake or food additives. They can be classified as toxic or nontoxic. Toxic reactions depend more on ingested substance or pharmacological properties of certain substances in food, while non-toxic reactions depend more on individual susceptibility. Non-toxic reactions are classified in non-immune mediated (food intolerance) or immune mediated reactions (food hypersensitivity and food allergy). Despite this didactic classification, symptoms of various adverse reactions to food are very similar to each other and can be mutually confused. ${ }^{1-3}$

According to the National Institute of Allergy and Infectious Diseases (NIAID), food allergy (FA) is defined as an adverse health effect arising from a specific immune response that occurs reproducibly on exposure to a given food. Food allergy can also be defined as a term used to describe adverse reactions to foods, dependent of immune mechanisms, IgE-mediated or non-IgE mediated. Therefore, food allergy implies an immunological mechanism underlying clinical symptoms expressed by patient. ${ }^{4-6}$

\section{Classification of food allergy}

Hypersensitivity reactions to foods are classified according to immunological mechanism involved ${ }^{7-9}-($ Figure 01$)$ : a) IgE-mediated reactions: result of sensitization to food allergens with formation of specific IgE antibodies, which binds receptors of mast cells and basophils. Next contacts to this same food and its connection with two molecules of $\operatorname{IgE}$ determine release of vasoactive mediators in neighbourhood that induce clinical manifestations of immediate hypersensitivity. Examples of common manifestations: skin reactions (dermatitis atopic, urticaria, angioedema), gastrointestinal (edema and itching of lips, tongue, or palate, vomiting and diarrhea), respiratory (asthma, rhinitis) and systemic reactions (anaphylaxis with hypotension and shock).

b) non IgE-mediated reactions: include cytotoxic reactions, immune complexes reactions and hypersensitive reactions mediated by cells. This group is represented by proctitis, enteropathy and enterocolitis induced by food protein.

c) mixed reactions (IgE-mediated and cell-mediated): this group includes manifestations of IgE mediated mechanisms, with participation of $\mathrm{T}$ lymphocytes and pro-inflammatory cytokines. Clinical examples: eosinophilic esophagitis, eosinophilic gastritis, eosinophilic gastroenteritis, atopic dermatitis, asthma and hemosiderosis.

Figure 1. Classification of adverse reactions to foods.

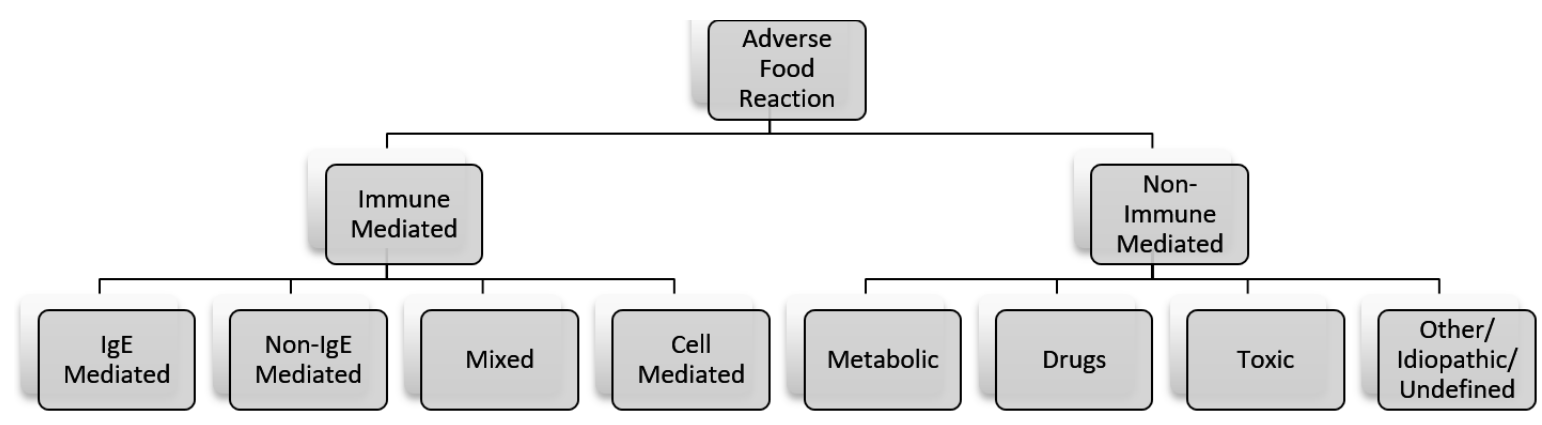

\section{Discussion}

\section{Epidemiology}

It is generally agreed in literature that food allergy is a common and on rise condition in population, especially in developed countries, although real reason for this is still uncertain (maybe consequence of hygiene hypothesis). Scientists estimate that about a quarter of population will have an adverse reaction to food during their lifetime. Therefore, this is a very import theme in immunology.

According to most sources studied in this essay, food allergy is a difficult condition to measure because of three main points: there is a plenty amount of foods reported to cause food allergy, but most prevalence studies have focused on only the most common food; incidence and prevalence of FA may have changed overtime, and many studies have indeed suggested a true rise in prevalence over time; studies of FA incidence, prevalence and natural history are difficult to compare because of inconsistencies and deficiencies in study design and variations in definition of FA.

Despite difficulties in study of food allergy, there are some agreement points in articles. First, FA is more common in children (6-8\%) than in adult (3-4\%). Second, food allergies are more common in patients with other allergic conditions (atopic dermatitis, asthma) than in general population. Third, food allergy is overrated, since a large portion of patients have symptoms, but in their sensitization tests they are negative. 
There are two major studies on topic of food allergy that are basis for most of epidemiology texts in this matter: metaanalysis by Rona et al., and systematic review by Zuidmeer et al., the first one talks about prevalence of allergy to peanut/ milk/egg/fish/crustacean shellfish, while the second one talks about prevalence of allergy to fruits/vegetables/non-peanut legumes/tree nuts/wheat/soy. Comparison between these two studies show that allergies related to peanut/milk/egg/fish/ crustacean shellfish are more common. Furthermore, it is interesting to note that allergies related to milk/wheat/egg/soy are temporary, while allergies related to peanut/nut/crustacean shellfish are permanent. ${ }^{10,11}$

\section{Risk factors}

FA is a complex and multifactorial process, which mixes genetic and environmental factors. There are three main risk factors to FA: genetic inheritance, diet and gastrointestinal microbiota. Genetic inheritance is represented by positive familiar history of allergenic processes or presence of allergenic conditions. Diet is represented by four main points: exclusive breastfeeding until six months, diet of pregnant/ nursing mother, age of introduction of solid foods/allergens and age of exposure to airborne allergens.

Severity of allergenic reactions to foods are multifactorial, variable and cannot be accurately predicted by degree of severity of past reactions or by level of IgE or size of skin prick test (SPT) wheal. Amount ingested, food form, co-ingestion of other foods, age of patient, degree of sensitization at time of ingestion, rapidity of absorption are some of the factors involved in severity of allergenic processes. ${ }^{4-6}$

\section{Structure and physiology of $\operatorname{IgE}$}

In human body there are several antibodies which are classified in different groups called immunoglobulins. There are 5 main immunoglobulins (Ig): IgA, IgG, IgM, IgD and IgE. Each Ig has its own properties, structure and function.

$\mathrm{IgE}$ structure is quite simple. It exists as a basic monomer and has an extra domain in constant region (CH4). It has an epsilon heavy chain, which consists of 5 domains. IgE has a Mr 190,000 and it has lowest serum concentrations of 0.0003 $\mathrm{mg} / \mathrm{ml}$ between immunoglobulins. The $\operatorname{IgE}$ main function is to bind to Fc receptors of mast cells and basophils and contact with antigens subsequently leading to the release of pro-inflammatory agents that result in allergenic symptoms. $\mathrm{IgE}$ also acts in parasitic helminthic diseases, once its serum levels rise in parasitic diseases. In parasitic helminthic disease, eosinophils bind to IgE-coated helminthic which results in killing the parasite. It is also important to notice that $\mathrm{IgE}$ does not fix complement. ${ }^{7-9,12,13}$

\section{Immune mechanism of food allergy}

Immune mechanisms that lead to development of adverse reactions to foods still need to be clarified in many aspects; however, there are some points that are already consensus in literature.
Initially, it is important to divide adverse reactions to foods in two main groups: food intolerance (non-immune process) and food allergies (immune-mediated process). Food allergies are subdivided into IgE-mediated reactions (atopic) or non-IgEmediated reactions. Allergic reactions to food, as mentioned above, are divided in IgE-mediated or non-IgE mediated. First one occurs in few minutes and it is related to Th2 response. The second one occurs in hours or days and it is related to Th1 immune response. Moreover, according to Geel and Coombs classification, IgE-mediated reactions are called type I (immediate) and are clinically related to anaphylaxis/ angioedema/urticaria, while non-IgE mediated reactions are called type IV (delayed or cell-mediated) and are clinically related to contact dermatitis.

Before starting this discussion, we need to review two important concepts: allergenicity versus antigenicity. Allergenicity consists in interaction between antigen and antibody, while antigenicity relates on abnormal immune response that causes clinical symptoms.

The gastro intestinal tract is the largest body surface area in contact with external environment (approximately 250 square meters). Therefore, it is an easy target for pathogenic microorganisms and allergens. Proof of this is that during our life we come in contact with about 2-3 tons of food, possible triggers of allergic reactions.

To prevent development of immune responses to any antigens in contact with mucosa of gastric tract, the body has developed specific and non-specific defense mechanisms. Non-specific defense mechanisms are: mechanical barrier (intestinal epithelium), intestinal microflora, biliary and pancreatic secretions and gastric tract motility. Specific mechanisms are: GALT system (gastrointestinal associated lymphoid tissue) and secretory immunoglobulin A (SIgA).

GALT system is a major constituent of lymph tissue in body. This consists of small sites distributed along digestive tract. GALT main function is regulate mucosal immunity, distinguishing pathogens from commensal microorganisms and food antigens. The GALT comprises Peyer's patches, mesenteric lymph nodes, LP and epithelium. Whose primary cells are B-lymphocytes, T lymphocytes, dendritic cells and special cells ("microfold," Paneth cells and intraepithelial lymphocytes).

IgA is an immunoglobulin found as a monomer that has $\mathrm{Mr}$ 160,000 and it represents $10 \%$ of normal serum Ig. Secretory $\operatorname{Ig} \mathrm{A}(\operatorname{SIg} \mathrm{A})$ is the first line of defense in the interface between external and internal environment. It is comprised of two IgA molecules associated with a "J" chain and it is present in secretions (tears, colostrum and gut, for example). Their functions are: inhibit bacterial adherence, neutralize toxins/ viruses, and prevent penetration of food antigens in epithelial barrier.

Before explaining molecular mechanisms involved in food allergy, it is necessary to address three basic concepts: gut barrier, oral tolerance induction and food allergens. Gut barrier 
(largest surface area of human body) is a single-cell layer of columnar intestinal epithelial cells that separates internal (sterile) and external environment, which its main functions are process ingested food and preventing penetration of harmful pathogens into body.

Oral tolerance induction is mediated by regulatory $\mathrm{T}$ cells: Th3 (CD4+) - produces TGF $\beta, \operatorname{Tr} 1(\mathrm{CD} 4+)$ - produces IL-10, CD4+CD25+ Treg, CD8+ suppressor $\mathrm{T}$ cells and $\gamma \delta \mathrm{T}$ cells. In healthy people after antigen presentation by dendritic cells (antigen presenting cells) in mesenteric lymph nodes, induction of Treg cells occurs. Therefore, CX3CR1 macrophages in mucosa can expand Treg cells. These cells inhibit Th2 cytokines, production of $\mathrm{IgE}$ and affects functions of mast cells/basophils. Consequently, inhibition of allergic inflammation and food hypersensitivity occurs. In summary, Treg controls and suppresses function of cells, regulating immune response after contact between antigens and gastrointestinal mucosa, therefore, avoiding excessive immune responses.

Food allergens are water-soluble glycoproteins with molecular weight of $10-70 \mathrm{kDa}$, thermostable, resistant to action of acids and proteases, and that can stimulate humoral immune response (IgE) or cellular immune response. There are two basic forms of a food inducing an allergic reaction: intake (class I allergen - ingested proteins) or inhalation (class II allergen - pollens). Cross-react is an unusual reaction that can still occur, i.e., reaction between antigenic determinant and antibody specific for a different antigen. Major food allergens are: milk, eggs, wheat, corn, peanuts, soy, fish and seafood.

When an antigen enters intestinal lumen in body of healthy individuals, it faces gastro-intestinal defense mechanisms above-mentioned. If it crosses epithelial barrier, it will eventually be captured by an $\mathrm{M}$ cell (microfold) or a dendritic cell (DC), or antigen-presenting cells (APC). The APC cell addresses itself to the closest mesenteric lymph nodes in order to present antigen to T lymphocytes present there. Depending on genetic predisposition of individual, APC cell activates different lineages of lymphocytes. In healthy individuals, Treg lymphocytes are activated, therefore, inducing oral tolerance. In susceptible individuals, occurs less activation of Treg cells and consequently activation of Th0 (naive helper $\mathrm{T}$ cells). Th0 cells can differentiate into Th1 or Th2. Th1 responses are related to hypersensibility (HS) IV (delayed or cell-mediated), while Th2 responses are related to HS I (immediate or IgEmediated).

Th1 immune response or HS type I (cell-mediated or delayed or non IgE-mediated) is the least common type of immune response in food allergies. In this type of immune response, after antigen presentation by APC cell occurs (mediated by low affinity receptors called FceRII), Th0 cells (näive T cells) produce IL-12 and differentiate into Th1 cells. Moreover, production of IL-2 by Th0 cells, maintains its self-production and, thus, it perpetuates Th1 immune response. Furthermore, there is a symbiotic interaction between Th1 lymphocytes and macrophages (effector cells), which maintains immune response. Th1 cells produce IFN- $\gamma$ and TNF- $\beta$ which stimulate activation of macrophages and, thus, their lytic activity. On other hand, macrophages produce IL-2 which stimulates Th1 cells, occurring, a positive feedback loop which self-perpetuates immune response. If this mechanism fails due to absence of dual-signal in antigen presentation, NK cells are activated and destroy infected cells, since they recognize sites that do not express cell receptors and, therefore, is a way to prevent evasion of pathogens from the immune system.

In summary, the main cells involved are Th1 lymphocytes, macrophage cells (effector cells) and NK (effector cells). The main cytokines involved are IL-2, whose functions are: T cell growth, B cell growth and Ig secretion, inhibition of Th2 lymphocyte proliferation; and IFN- $\gamma$, whose main functions are: inhibit IL-4 and IL-5 effects on B cells, increase MHC expression on macrophages and $\mathrm{B}$ cells.

Th2 immune response or HS type IV (IgE-mediated or immediate) is the most common type of immune response in food allergies. In this type of immune response, after antigen presentation by APC cell occurs (mediated by high affinity receptors called FceRI), Th0 cells (näive T cells) produce IL-4 and differentiate into Th2 cells. Moreover, production of IL- 2 by Th0 cells, maintains its self-production and, thus, it perpetuates Th2 immune response. Th2 cells produce IL-3, IL-4, IL-5, IL-6, IL-10 and IL-13 which stimulate activation of mast cells, basophils, B cells and eosinophils.

Subsequently, activation of Th2 immune response itself occurs. In other words, LB produces $\mathrm{IgE}$, and then it binds to mast cells releasing inflammatory mediators. In association, less activation of Treg cells occurs and, thus, there is less control of immune response. Therefore, allergic response is triggered. This process makes immune cells of mucosa sensitized to specific glycoproteins. Thus, in a possible re-exposure to antigens, activation of memory $\mathrm{T}$ cells happens. Those cells secrete Th2 interleukins that leads to induction of increased production of IgE. Afterwards, antigen-antibody interaction happens and it activates mast cells and basophils. Those cells degranulate, releasing important cytokines in late phase of IgE-mediated response, e.g. histamine, prostaglandins and leukotrienes. Histamine causes vasodilatation (shock), it increases smooth muscle contraction (bronchospasm and diarrhoea), and it increases mucus secretion. So, histamine mediates symptoms of allergic attack. It is important to note that mast cells also produce TNF $\alpha$, which induces recruitment of neutrophils (effector cells). Concomitantly, cytokines produced by Th2 lymphocytes activates eosinophils that end up destroying parasites or tissues (cytotoxic effector cells).

In summary, the main cells involved are Th2 lymphocytes, B lymphocytes, mast cells and basophils, eosinophils (cytotoxic effector cells). The main cytokines involved are IL-4, whose functions are: stimulate B cell growth and differentiation, stimulate Ig secretion (Ig M and IgG); and IL-6, whose main functions are: stimulate $\mathrm{B}$ cell growth and differentiation (IgA), stimulate eosinophil growth and differentiation; and IL10, whose main functions are: inhibit IFN- $\gamma$ production and inhibit macrophages production. The main immunoglobulin 
involved is IgE, whose functions are: sensitization of mast cells, enhance FceRI expression and enhance release of serotonin and IL-4 and IL-6. Observe that complement can still stimulate mast cell-mediated inflammatory reactions.

It is important to mention that antigen sensitization is divided in two phases. Phase 1 is an immediate alteration of tissue permeability and transcellular passage of antigen. Phase 2 is a morphologic activation of mast cells and transcellular/ paracellular passage of antigen with further alteration in tissue permeability. ${ }^{7-9,12-14}$

\section{Symptoms of food allergy}

Food allergies can be manifested in different ways and in different degrees of severity, making this disease eminently clinical, as discussed in next section. In order to facilitate studies and comprehension of those symptoms, it can be divided into different classes according to different parameters. It is important to note that symptoms rarely appear isolated.

Initially, we can classify symptoms according to system or organ involved: gastro-intestinal tract, skin, respiratory tract and general symptoms. Respiratory tract manifests itself by regurgitation, vomiting, diarrhoea, constipation, haematochezia, melena and anaemia. Skin manifests itself with atopic dermatitis, angioedema and urticaria. Finally, respiratory tract manifests itself by rhinorrhoea, chronic coughing and wheezing. General symptoms are cramping or persistent irritability.

We can also classify food allergies according to the age of individuals affected. The most prevalent symptoms in children are nausea/vomiting, abdominal pain, failure to thrive. In adults, the most common symptoms are dysphagia, fecal impaction, and heartburn.

Finally, we can classify food hypersensitivities according to immune mechanism involved. IgE-mediated hypersensitivity main symptoms are gastro-intestinal hypersensitivity, oral allergy syndrome, acute urticaria, angioedema, acute bronchospasm and anaphylaxis. Non IgE-mediated hypersensitivity main symptoms are enterocolitis/ proctitis/enteropathy, herpetiformis dermatitis, pulmonary hemosiderosis. Mixed hypersensitivity main symptoms are eosinophilic gastroenteritis, atopic dermatitis, asthma, and anaphylaxis. ${ }^{12,14,15}$

\section{Diagnosis of food allergy and differential diagnosis}

In diagnosis of food allergies it is important to be aware that clinical history is paramount, like most medical conditions. Therefore, additional tests have only the function of confirming and clarifying assumptions already made by a good history. Furthermore, it is essential to emphasize that exams depend on the immune mechanism involved.

Complementary tests can be divided into three main types: determination of serum specific IgE, oral triggering tests and specific evidence.
Determination of serum specific IgE can be subdivided into three basic groups: in vivo, in vitro and or serological markers. In vivo tests or skin hypersensitivity tests are considered positive when there is formation of wheal with at least $3 \mathrm{~mm}$ (average diameter), reaction in positive control (histamine solution) and no wheal in negative control (vehicle solution). In vitro tests or serum specific $\operatorname{IgE}$ (ImmunoCAP ${ }^{\circledR}$ System) has as its main problem cross-reactivity. Serological markers are quantification of histamine released by basophils, determination of levels of specific serum $\operatorname{IgG}$ and $\operatorname{IgG} 4$, research and quantification of antigen-antibody complexes, determination of CD63 expression on basophils, determination of levels of $\operatorname{IgA}$ antibodies antigliadin, anti-endomysium and anti-transglutaminase.

Oral triggering tests are considered only reliable for establishing diagnosis of food allergy methods; it may be subdivided into three types: open, single blind or double blind. Double blind test is considered gold standard for diagnosing food allergies.

Specific evidence constitutes morphological and functional evaluation of gastrointestinal tract. The main methods used are gastric endoscopies associated with multiple biopsies, determination of $\alpha 1$-antitrypsin in dissected faeces and D-xylose absorption tests. ${ }^{15-17}$

\section{Prevention of food allergy}

High risk allergy children are those that have at least one first-degree relative with a history of allergy. The main recommendations in these cases are exclusive breastfeeding for six months and complete up to two years or more, measured use of general preventive, environmental control and evaluation of bio-psycho-social context. Hypoallergenic formulas are still indicated for supplementation or complementation of high-risk children and maternal dietary restriction during lactation with calcium and vitamins supplementation.

Prevention can be divided into three basic classes: primary, when intervention is performed before exposure to allergens (prevention of sensitization); secondary prevention, between sensitization and development of allergic symptoms; and tertiary prevention, which refers to treatment of allergic diseases, to reduce severity of symptoms and disease progression. ${ }^{4}$

\section{Treatments of food allergy}

The treatment of food allergy can be divided according to severity. In urgency is important to interrupt food involved and symptom relief with epinephrine/anti-histamine/ bronchodilator/anti-emetics and anti-spasmodic, associated with hospitalization of patient. It is important to identify patients who are progressing to more severe reactions in those phases. In an emergency you encourage proper management of anaphylactic frames with patient stabilization and administration of adrenaline. In office arrives drawn over frames that require elaborate clinical history with establishment of a precise differential diagnosis. In such cases, the only effective treatment recommended is absolute charge of food restriction diet of patient with this awareness. 
However, we can use pharmacological treatments such as antihistamines and systemic corticosteroids. Future prospects include prevention through proper breastfeeding, probiotics and immune modulation. . $^{46,17}$

\section{Final considerations}

\section{Desensitization: definition, immune mechanism and usage}

A food allergy is an immune disease which lacks full cure; there is possibility of preventive or symptomatic relief through use of antihistamines and corticosteroids. It was believed that the only really effective treatment for FA would be complete allergen restriction. However, from 1984 this paradigm began to change, emerging the concept of oral immunotherapy or desensitization. Today, renowned research facilities (University of Cambridge, University of Duke, Mount Sinai School of Medicine and University of São Paulo) are already using this new technique in treatment of food allergies.

Oral immunotherapy is a process in which patient receives small progressive doses of food allergy until body has become tolerant and able to ingest larger amounts. Therefore, it acts similar to a vaccine. This therapy is indicated in cases of persistent food allergy, i.e., that is present since childhood and perpetuated after five years or even adulthood. This concept lies in the fact that most allergies are cured as the child grows.

The immune mechanism which bases desensitization still has some nuances to be discussed. However, there are some hypotheses proposed: antigen-driven suppression, clonal anergy, clonal deletion and bystander suppression.

\section{REFERENCES}

1. Bricks LF. Adverse food reactions in childhood. Food intolerance and food allergy - an Update. Pediatria (São Paulo). 1994;16(4):176-85.

2. Sociedade Brasileira de Pediatria; Associação Brasileira de Alergia e Imunopatologia. Consenso brasileiro sobre alergia alimentar: 2007. Rev Bras Alerg Imunopatol. 2008;31(2):1-71.

3. Ferreira CT, Seidman E. Food allergy: a practical update from gastroenterological viewpoint. J Pediatr (Rio J). 2007;83(1):7-20.

4. Oyoshi MK, Oettgen HC, Chatila TA, Geha RS, Bryce PJ. Food allergy: insights into etiology, prevention, and treatment provided by murine models. J Allergy Clin Immunol. 2014;133(2):309-17.

5. Sicherer SA, Sampson HA. Food allergy. J Allergy Clin Immunol. 2010;125(2 Suppl 2):116-25.

6. Sampson HA. Update on food allergy. J Allergy Clin Immunol. 2004;113(5):805-19.

7. Metacalfe DD. Immune mechanisms in food allergy. Clin Exp Allergy. 1991;21(1):321-4.

8. Sampson HA, Burks AW. Mechanisms of food allergy. Annu Rev Nutr. 1996;16:161-77.
Desensitization technique consists of four basic steps: 1 . Dilute food in low concentrations, i.e., a dose to which the patient has no allergic reaction; 2. perform tests to find the threshold of the patient; 3 . desensitization itself: repeated exposure to multiple daily doses; 4. gradually increasing doses until patient tolerates an amount so large that it is possible exposure to food without reaction (population of resistant cells is large enough for a person to have no more allergy symptoms). It is important to mention that the combination of oral immunotherapy and monoclonal antibody against Ig E (Omalizumab) has been shown to be a promising therapy for the future. ${ }^{18-21}$

There are some features and concepts that need to be discussed when it talks about desensitization. Initially, it is important to reaffirm that this technique does not effectively cure the patient, but he becomes tolerant. The first work with desensitization (developed in 1984) has already reached $73 \%$ of efficiency and more recent researches at University Hospital of University of São Paulo (2013) already reaches $90 \%$ of efficiency. Usually it takes up to 12 to 15 sessions, which means about 3 months of treatment. However, treatment should be individualized and supervised because of grave risk of anaphylactic reactions.

Finally, there is restriction that patient must have more than five years and have a diagnosis of persistent allergic. This is because there is a need for maintenance of immune memory through continuous contact with allergens and this is only possible with common food of day-to-day (e.g., milk, eggs and cereals); while adults typically have allergies to food easier to be removed from diet (seafood and almonds), therefore, it is necessary a guided exclusion of food diet and developing a plan of action in case of accidental exposure. ${ }^{22-25}$

9. Helm RM, Burks AW. Mechanisms of food Allergy. Curr Opin Immunol. 2000;12(6):647-53.

10. Rona RJ, Keil T, Summers C, Gislason D, Zuidmeer L, Sodergren E, et al. The prevalence of food allergy: a meta-analysis. J Allergy Clin Immunol. 2007;120(3):638-46.

11. Zuidmeer L, Goldhahn K, Rona RJ, Gislason D, Madsen C, Summers C, et al. The prevalence of plant food allergies: a systematic review. J Allergy Clin Immunol. 2008;121(5):1210-18.

12. Sampson HA. Food allergy. Part 1: immunopathogenesis and clinical disorders. J Allergy Clin Immunol. 1999;103(5 Pt 1):71728 .

13. Pereira AC, Moura SM, Constant PB. Food allergy: system immunologic and main food involved. Semina: Ciências Biológicas e da Saúde. 2008;29(2):189-200.

14. Sampson HA, Sicherer SA. Food allergy: epidemiology, pathogenesis, diagnosis, and treatment. J Allergy Clin Immunol. 2014;133(2):291-307.

15. Sampson HA. Food allergy: part 2: diagnosis and management. J Allergy Clin Immunol. 1999;103:981-9. 
16. Boyce JA, Assa'ad A, Burks AW, Jones SM, Sampson HA, Wood RA, et al. Guidelines for the diagnosis and management of food allergy in the United States: report of NIAID-Sponsored Expert Panel. J Allergy Clin Immunol. 2010;126(6 suppl):1-58.

17. Associação Brasileira de Alergia e Imunopatologia, eSociedade Brasileira de Alimentação e Nutrição. Guia prático de diagnóstico e tratamento da alergia às proteínas do leite de vaca mediada pela imunoglobulina E. Rev Bras Alerg Imunopatol. 2012;35(6):203-33.

18. Cavenaghi B, Sanches MR, Diniz SN. A importância do tratamento de dessensibilização na alergia às proteínas do leite de vaca (APLV). Enciclopédia Biosfera, Centro Científico Conhecer. 2013;9(17):2883-2903.

19. Martins MS, Galeazzi MA. Alergia alimentar: considerações sobre o uso de proteínas modificadas enzimaticamente. Revista Cadernos de Debate. 1996;IV:89-110.

20. Patriarca G, Schiavino D, Nucera E, Schinco G, Milani A, Gasbarrini GB. Food allergy in children: results of a standardized protocol for oral desensitization. Hepatogastroenterology. 1998;45(19):52-8.
21. Oliveira S, Câmara R, Marques S, Prates S, Almeida MM, Pinto JR. Food tolerance induction: fiction or reality? Revista Portuguesa de Imunoalergologia. 2005;13(4):347-56 .

22. Burton OT, Novas Rivas M, Zhou JS, Logsdon SL, Darling AR, Koleoglou KJ, et al. Immunoglobulin E signal inhibition during allergen ingestion leads to reversal of established food allergy and induction of regulatory T cells. Immunity. 2014;41(1):141-51.

23. Patriarca G, Nucera E, Roncallo C, Pollastrini E, Bartolozzi F, De Pasquale $\mathrm{T}$, et al. Oral desensitizing treatment in food allergy: clinical and immunological results. Aliment Pharmacol Ther. 2003;17(3):459-65.

24. Naspitz CK, Solé D, Jacob CA, Sarinho E, Soares FJ, Dantas V, et al. Sensitization to inhalant and food allergens in Brazilian atopic children by in vitro total and specific IgE assay. Allergy Project PROAL. J Pediatr (Rio J). 2004;80(3):203-10.

25. Staden U, Rolinck-Werninghaus C, Brewe F, Wahn U, Niggemann B, Beyer K. Specific oral tolerance induction in food allergy in children: efficacy and clinical patterns of reaction. Allergy. 2007;62(11):1261-9.

\section{How to cite:}

Farias AL, Castelo Branco HF Junior, Castelo Branco HC. Food allergy: is desensitization an effective treatment strategy in patients with peanut allergy? Rev Med UFC. 2019 abr-jun;59(2):33-39. 